\title{
Design, Synthesis, Molecular Modelling and Biological Evaluation of Novel $\alpha$-Naphtholhydroxamate Derivatives as Potential Anticancer Agents
}

\author{
Adel S Abdelrahim ${ }^{1 *}$, Syam Mohan², Mohamed Albarrati ${ }^{3}$, Hafiz Makeen ${ }^{3}$ and Safhi MM ${ }^{4}$ \\ ${ }^{1}$ Pharmaceutical Chemistry Department, Faculty of Pharmacy, Al-Azhar University, Cairo, Egypt \\ ${ }^{2}$ Medical Research Centre, Jazan University, Saudi Arabia \\ ${ }^{3}$ Department of Clinical Pharmacy, Faculty of Pharmacy, Jazan University, Saudi Arabia \\ ${ }^{4}$ Department of Pharmacology, Faculty of Pharmacy, Jazan University, Saudi Arabia
}

\begin{abstract}
Chemotherapy is one of the treatment options for cancer. A major problem in cancer chemotherapy is the lack of selective toxicity of many commonly used anti-cancer agents towards tumor tissue compared to normal tissue. Studies have shown that $\alpha$-naphthol is selectively toxic to cultures of human tumor tissue compared to normal tissues in vitro. Hence, this study was conducted to synthesize a series of new hydroxamate derivatives containing $\alpha$-naphthol nucleus by the reaction of naphthol acetic acid with amino acid methyl ester derivatives which were directly reacted with hydroxyl amine at room temperature. Structures of these compounds were confirmed by standard studies of IR, ${ }^{1} \mathrm{H}$ NMR, ${ }^{13} \mathrm{CNMR}$, MS and elemental analysis. The cytotoxicity of the synthesized compounds were studied using the MTT assay in four human cancer cell lines, including HepG2, PC-3, HT-29 and MCF-7. Among the compounds, compound $6_{\mathrm{g}}$ and $6_{\mathrm{h}}$ exhibited a significant cytotoxicity against almost all the used cells including the normal cells (WRL-68). Further studies have shown that the cell death observed was closely associated with generation of reactive oxygen species (ROS). In this study, other naphthol derivatives have shown significant increase in the level of ROS in concentration dependent manner in treated cells. In conclusion, the study has shown that among the synthesized compounds, compounds $\mathbf{6}_{\mathrm{g}}, \mathbf{6}_{\mathrm{k}}$ and $\mathbf{6}_{\mathrm{h}}$ hold the potential for further research. Furthermore, a molecular docking of the tested compounds was carried out to investigate their binding pattern with the prospective target, HDAC (PDB-code: 1T69).
\end{abstract}

Keywords: Chemotherapy; Cancer; Enzyme; Haemoglobin

\section{Introduction}

Cancer is one of the major health complications around the globe including United States of America. Presently cancer is the second leading cause of medical death in the US, and is anticipated to exceed heart diseases as the leading cause of death in the coming next few years [1]. According to Council of Health Service breast cancer is the most common cancer among Saudis with 15\% of whole reported cancer. In addition classification among sex showed that colorectal cancer is the highest incidence in men, followed by leukaemia and liver. Among the children, leukaemia stands in first place followed by brain and Hodgkin disease [2].

For the last four decades, a number of potential approaches have been proposed for the treatment of cancer. One of the recent targets is Histone deacetylase (HDAC). Modification of histone acetylation level, promoted by HAT and HDAC enzymes, has been recognized to play an important role in the epigenetic modulation of gene expression; in fact this well-known post-translational mechanism is highly involved in the modulation of chromatin plasticity and in the regulation of transcriptional factors accessibility to DNA [3]. Therefore the disruption of histone acetylation pattern is supposed to determine transcriptional disorders and is related to several malignant diseases [4]. Inhibition of HDAC enzyme has proven to induce antiproliferative effects and to promote cellular differentiation. For these reasons, discovery of new agents targeting HDAC enzyme is considered of great interest for the development of anticancer drugs [5].

Hydroxamic acids are among the most well studied compounds due to their significance in so many different applications in modern society. Since it was discovered the first of these acids more than 100 years ago, an extraordinary amount of work has been carried out on the design, preparation, structure-activity relationships (SAR), utilization, and use potential of the hydroxamic acids. These compounds are capable of the inhibition of a variety of enzymes, including ureases, peroxidases, and matrix metalloproteinases. They are also capable of competing as siderophores for iron-(III). In the biomedical sciences, hydroxamic acid moieties are used in the design of therapeutics targeting cancer [6].

The ever-increasing importance of hydroxamic acid functionality in the design of a wide spectrum of bioactive agents, especially of highly potent and selective inhibitors of disease-related metalloproteinases, has heightened the interest in the synthesis of hydroxamic acidbased small molecules [7]. Hydroxamic acids are able to chelate metal ions and therefore inhibit metal-containing enzymes such as matrix metalloproteinases (MMPs). Over expression of MMPs has been linked to a variety of diseases including cancer, rheumatoid arthritis, osteoarthritis and cardiovascular disease [8].

a-Naphthol is selectively toxic to short-term organ cultures of human colonic tumor tissue compared to normal intestinal mucosa taken from the same patients and to human colonic cell lines in vitro [9]. 2-Hydroxymethyl-naphthol diacetate, a naphthol derivative, possesses potent cytotoxic activities in human cancer cell lines [9]. Also (+)-3-(2-(2-fluorobenzyloxy) naphthalen-6-yl)-2-aminopropanoic acid derivatives were identified as reversible and competitive protein

*Corresponding author: Adel S Abdelrahim, Pharmaceutical Chemistry Department, Faculty of Pharmacy (Boys), Al-Azhar University, Cairo, 11884, Egypt Tel: 25910439; Fax: 25916866; E-mail: dr_adelabdelrahim@yahoo.com

Received November 02, 2016; Accepted November 16, 2016; Published November 23, 2016

Citation: Abdelrahim AS, Mohan S, Albarrati M, Makeen H, Safhi MM (2016) Design, Synthesis, Molecular Modelling and Biological Evaluation of Novel a-Naphtholhydroxamate Derivatives as Potential Anticancer Agents. Med Chem (Los Angeles) 6: 682-689. doi:10.4172/2161-0444.1000415

Copyright: $\odot 2016$ Abdelrahim AS, et al. This is an open-access article distributed under the terms of the Creative Commons Attribution License, which permits unrestricted use, distribution, and reproduction in any medium, provided the original author and source are credited. 
Citation: Abdelrahim AS, Mohan S, Albarrati M, Makeen H, Safhi MM (2016) Design, Synthesis, Molecular Modelling and Biological Evaluation of Novel a-Naphtholhydroxamate Derivatives as Potential Anticancer Agents. Med Chem (Los Angeles) 6: 682-689. doi:10.4172/21610444.1000415

tyrosine phosphatases (PTP) inhibitors via a structure-based design approach [9]. 2-Phenylnaphthalenoids derivatives represent a novel type of Top II inhibitory scaffold for developing new antitumor chemotherapeutic agents [10]. Another naphthol derivative has been synthesized and it is found that it is a cell-permeable small molecule inhibitor of KIX-KID interaction, an essential interaction for CREBdependent gene transcription activation. As a result, this compound is able to inhibit CREB-mediated gene transcription in living cells [11].

\section{Rational of molecular design}

Figure 1 showed the basic structural requirements (pharmacophoric features) of histone deacetylase 1 inhibitors; i) Surface recognition Group, ii) Linker group, iii) metal binding group [12]. In addition, it showed some reported histone deacetylase 1 inhibitors with illustration of pharmacophoric features as Vorinostat I [13], Panobinostat II [14], Belinostat III [15], R306465 IV [16] and compound V [17]. Optimistic by the above observations, we turn our concentration to synthesize a library of novel hybrid compounds comprising hydroxamate moiety with $\alpha$-naphthol and different linkers of amino acids conjugate. Moreover, chemical modification was carried out to synthesize another series of compounds bearing two hydroxamate moieties. The main core of our design is the investigation of the anticancer activities of these new compounds. Also, we are aiming to study the structure activity relationships (SARs), hoping to obtain more potent anticancer agents.

\section{Experimental}

\section{Chemistry}

All the chemicals were obtained from Merck, Fluka, Sigma and Aldrich Companies and used without further purification. Melting points were measured using Thermo Fisher Scientific. IR spectra were recorded Bruker tensor 27, FT-IR Spectrophotometer. All ${ }^{1} \mathrm{H}$ NMR

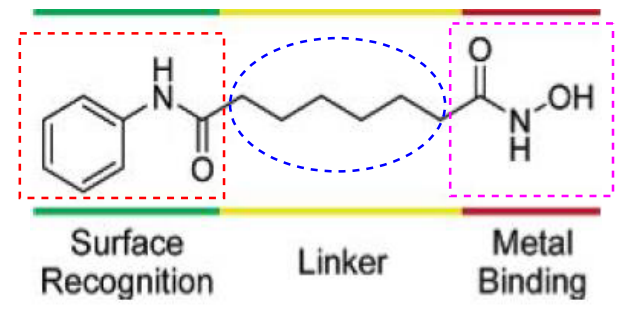

Vorinostat (I)

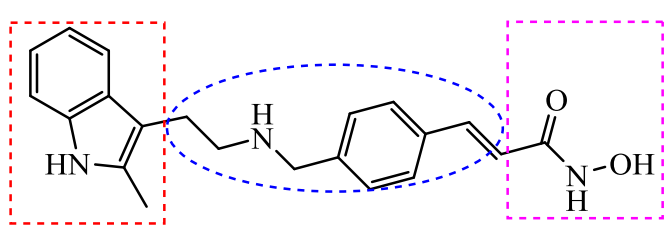

Panobinostat (II)

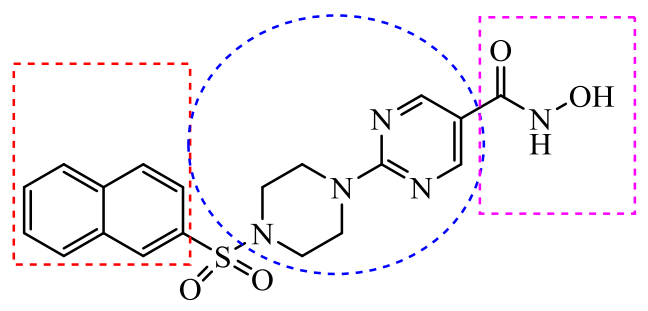

R306465(IV)

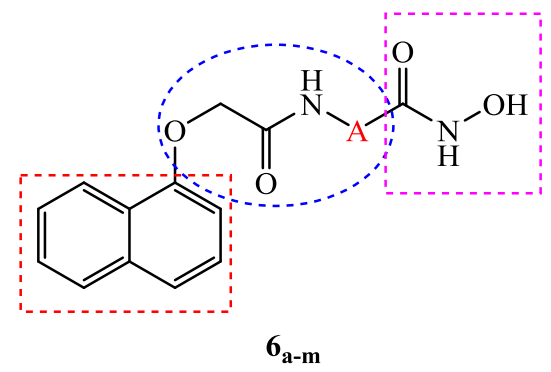

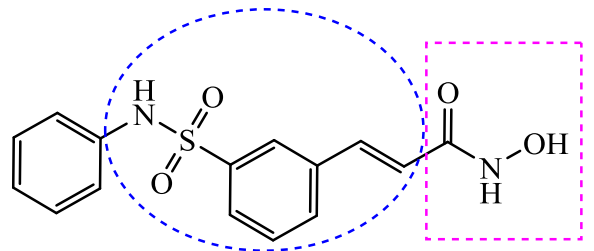

Belinostat (III)<smiles>O=C(CCCC1CCN(S(=O)(=O)c2cccc3ccccc23)CC1)NO</smiles>

(V)<smiles>O=C(COC(=O)C(C(=O)NO)C(=O)NO)NC(=O)COc1cccc2ccccc12</smiles>

9 a,b

Figure 1: Pharmacophoric features of reported HDAC inhibitors and the synthesized compounds. 
Citation: Abdelrahim AS, Mohan S, Albarrati M, Makeen H, Safhi MM (2016) Design, Synthesis, Molecular Modelling and Biological Evaluation of Novel a-Naphtholhydroxamate Derivatives as Potential Anticancer Agents. Med Chem (Los Angeles) 6: 682-689. doi:10.4172/21610444.1000415

spectra were recorded on a Bruker $400 \mathrm{MHz}$ Spectrophotometer. Chemical shifts are reported in parts per million (ppm) using tetramethylsilane (TMS) as an internal standard. Ultraviolet-visible (UV-vis) absorption spectra were recorded on Perkin-Elmer spectrophotometer at the wavelength of maximum absorption ( $\mathrm{kmax})$ in a range of DMSO at same concentrations $\left(1 \times 10^{-6} \mathrm{M}\right)$. The mass Spectra were run on a Shimadzu Qp 5050 Ex Spectrometer. The microanalyses for $\mathrm{C}, \mathrm{H}$ and $\mathrm{N}$ were performed on Perkin-Elmer elemental analyzer.

Naphthol acetic acid (3): $\alpha$-Naphthol(1) (1.44 gm, $10 \mathrm{mmol})$ was dissolved in dry acetone $(50 \mathrm{~mL})$ and then anhydrous potassium carbonate $(2.74 \mathrm{gm}, 20 \mathrm{mmol})$ and chloroacetic acid (2) (0.94 gm, $10 \mathrm{mmol}$ ) were added. The mixture reaction was refluxed overnight and the reaction was checked by TLC. After completion, the reaction mixture was filtered while hot and the solvent was concentrated to produce the title compound (3) [9].

Naphthol amino acid methyl ester derivatives $\left(5_{\mathrm{a}-\mathrm{m}}\right)$ : Compound (3) $(1.5 \mathrm{gm}, 7 \mathrm{mmol})$ was refluxed with thionyl chloride $(10 \mathrm{~mL})$ for 3 $\mathrm{h}$ and the solvent was removed under reduced pressure and the residue was dissolved in dichloromethane $(50 \mathrm{~mL})$ and then trimethylamine (3 $\mathrm{mL}, 30 \mathrm{mmmol}$ ) and amino acid methyl ester hydrochloride derivatives (4) were added $(10 \mathrm{mmol})$ and the reaction mixture was stirred for $24 \mathrm{~h}$ at room temperature. The reaction was checked by TLC and after completion; the reaction mixture was shaken with $5 \%$ of hydrochloric acid solution followed by washing with saturated solution of potassium bicarbonate. Then the organic layer was separated, dried using anhydrous magnesium sulphate and evaporated to produce the title compound (5) that was used directly without purification.

Naphthol amino acid hydroxamate derivatives $\left(6_{\mathrm{a}-\mathrm{m}}\right)$ : Naphthol amino acid methyl ester derivatives $\left(5_{\mathrm{a-m}}\right)(10 \mathrm{mmol})$, potassium hydroxide ( $2.80 \mathrm{gm}, 50 \mathrm{mmol}$.) and hydroxyl amine hydrochloride ( $2 \mathrm{gm}, 30 \mathrm{mml})$ were added to dry methanol $(50 \mathrm{ml})$ in ice bath and continuous stirring for $0.5 \mathrm{~h}$ and then at room temperature for $12 \mathrm{~h}$. The solvent mixture was removed under vacuum and the residue was dissolved in water and stirred with diethyl ether $(2 \times 50 \mathrm{~mL})$ and the aqueous layer was separated and acidified with $5 \% \mathrm{HCl}$. The precipitate was filtered and recrystallized from methanol to produce the product $\left(6_{\mathrm{a}-\mathrm{m}}\right)$.

(i) N-Hydroxy-2-(2-(naphthalen-1-yloxy)acetamido)acetamide (6) : Yield: $1.15 \mathrm{gm}(42 \%)$ as a solid; $\mathrm{mp} 120-123^{\circ} \mathrm{C}$. IR $(\mathrm{KBr}) \mathrm{m}: 3300$, $3050,1650 \mathrm{~cm}^{-1},{ }^{1} \mathrm{H}$ NMR $\left(\mathrm{CDCl}_{3}, 300 \mathrm{MHz}\right): \delta 9.04$ (s, NH), 8.34-6.65 (m, 8H), 4.45 (s, 2H, $\left.\mathrm{CH}_{2}\right), 4.00\left(\mathrm{~s}, 2 \mathrm{H}, \mathrm{CH}_{2}\right), 2.00(\mathrm{~s}, 1 \mathrm{H}, \mathrm{OH}) ;{ }^{13} \mathrm{NMR}$ $\left(\mathrm{CDCl}_{3}, 300 \mathrm{MHz}\right): \delta 168,166,156,134,127,126,120,66,39123,127$, 120, MS (EI) m/z: 274.10 (100.0\%), 275.10 (15.5\%), 276.10 (2.0\%). Anal. Calcd for $\mathrm{C}_{14} \mathrm{H}_{14} \mathrm{~N}_{2} \mathrm{O}_{4}$ : C, 61.31; H, 5.14; N, 10.21; Found: C, $61.00 ; 4,98 ; \mathrm{N}, 10.31$.

(ii) N-Hydroxy-2-(2-(naphthalen-1-yloxy)acetamido) propanamide $\left(6_{\mathrm{b}}\right)$ : Yield: $1.64 \mathrm{gm}(57 \%)$ as a solid; $\mathrm{mp} 115-116^{\circ} \mathrm{C}$. IR (KBr)m: 3300, 3050, $1650 \mathrm{~cm}^{-1},{ }^{1} \mathrm{H}$ NMR $\left(\mathrm{CDCl}_{3}, 300 \mathrm{MHz}\right): \delta 8.34-$ $6.65(\mathrm{~m}, 9 \mathrm{H}), 4.45\left(\mathrm{~s}, 2 \mathrm{H}, \mathrm{CH}_{2}\right), 4.71(\mathrm{~m}, 1 \mathrm{H}, \mathrm{CH}), 2.00(\mathrm{~s}, 1 \mathrm{H}, \mathrm{OH})$, $1.48\left(\mathrm{t}, 3 \mathrm{H}, \mathrm{CH}_{3}\right) ;{ }^{13} \mathrm{NMR}\left(\mathrm{CDCl}_{3}, 300 \mathrm{MHz}\right): \delta 169,168,156,134,127$, $126,120,66,39123,127,120,67,45,17 ;$ MS (EI) m/z: : $288.11(100.0 \%)$, 289.11 (17.0\%), 290.12 (2.1\%). Anal. Calcd for $\mathrm{C}_{15} \mathrm{H}_{16} \mathrm{~N}_{2} \mathrm{O}_{4}: \mathrm{C}, 62.49 ; \mathrm{H}$, 5.59; N, 9.72; Found: C, 62.20; H, 5,50 ; N, 9.89.

(iii) N-Hydroxy-3-(2-(naphthalen-1-yloxy)acetamido) propanamide (6): Yield: $1.72 \mathrm{gm}(60 \%)$ as a solid; $\mathrm{mp} 130-133{ }^{\circ} \mathrm{C}$. IR (KBr)m: 3300, 3050, $1650 \mathrm{~cm}^{-1},{ }^{1} \mathrm{H}$ NMR $\left(\mathrm{CDCl}_{3}, 300 \mathrm{MHz}\right): \delta$ 8.34-6.65 (m, 9H), $4.45\left(\mathrm{~s}, 2 \mathrm{H}, \mathrm{CH}_{2}\right), 3.71\left(\mathrm{~m}, 2 \mathrm{H}, \mathrm{CH}_{2}\right), 2.66(\mathrm{~m}, 2 \mathrm{H}$,
$\left.\mathrm{CH}_{2}\right), 2.00(\mathrm{~s}, 1 \mathrm{H}, \mathrm{OH}) ;{ }^{13} \mathrm{NMR}\left(\mathrm{CDCl}_{3}, 300 \mathrm{MHz}\right): \delta 169,168,156,134$, $127,126,120,66,39123,127,120,67,45,42,37 ; \mathrm{MS}$ (EI) m/z: : 288.11 (100.0\%), 289.11 (17.0\%), 290.12 (2.1\%). Anal. Calcd for $\mathrm{C}_{15} \mathrm{H}_{16} \mathrm{~N}_{2} \mathrm{O}_{4}$ : C, 62.49; H, 5.59; N, 9.72; Found: C, 62.32; H, 5,65; N, 9.85.

(iv) N-Hydroxy-3-mercapto-2-(2-(naphthalen-1-yloxy) acetamido)propanamide $\left(\mathbf{6}_{\mathrm{d}}\right)$ : Yield: $0.9 \mathrm{gm}(28 \%)$ as a solid; $\mathrm{mp} 105$ $108^{\circ} \mathrm{C}$. IR (KBr)m: 3300, 3050, $1650 \mathrm{~cm}^{-1},{ }^{1} \mathrm{H}$ NMR $\left(\mathrm{CDCl}_{3}, 300 \mathrm{MHz}\right)$ : $\delta 8.34-6.65(\mathrm{~m}, 9 \mathrm{H}), 4.67\left(\mathrm{~s}, 2 \mathrm{H}, \mathrm{CH}_{2}\right), 4.54(\mathrm{~m}, 1 \mathrm{H}, \mathrm{CH}), 2.66(\mathrm{~m}, 2 \mathrm{H}$, $\left.\mathrm{CH}_{2}\right), 2.00$ (s, 1H, OH), 1.49 (s, $\left.1 \mathrm{H}, \mathrm{SH}\right) ; ;{ }^{13} \mathrm{NMR}\left(\mathrm{CDCl}_{3}, 300 \mathrm{MHz}\right): \delta$ $169,168,156,134,127,126,120,66,39123,127,120,67,45,37$; MS (EI) m/z: 320.08 (100.0\%), 321.09 (16.6\%), 322.08 (4.6\%), 322.09 (2.2\%), 321.08 (1.5\%). Anal. Calcd for $\mathrm{C}_{15} \mathrm{H}_{16} \mathrm{~N}_{2} \mathrm{O}_{4} \mathrm{~S} \mathrm{C}, 56.24 ; \mathrm{H}, 5.03 ; \mathrm{N}, 8.74$; Found: C, 56. 18; H, 4,93; N, 8.64 .

(v) N-Hydroxy-4-methyl-2-(2-(naphthalen-1-yloxy)acetamido) pentanamide $\left(6_{\mathrm{e}}\right)$ : Yield: $1.70 \mathrm{gm}(51 \%)$ as a solid; $\mathrm{mp} 125-128^{\circ} \mathrm{C}$. IR (KBr)m: 3300, 3050, $1650 \mathrm{~cm}^{-1},{ }^{1} \mathrm{H}$ NMR ( $\left.\mathrm{CDCl}_{3}, 300 \mathrm{MHz}\right): \delta 8.34-$ $6.65(\mathrm{~m}, 9 \mathrm{H}, \mathrm{Ar}, 2 \mathrm{NH}), 4.92\left(\mathrm{~m}, 3 \mathrm{H}, \mathrm{CH}, \mathrm{CH}_{2}\right), 2.00(\mathrm{~s}, 1 \mathrm{H}, \mathrm{OH}), 1.76$ $\left(\mathrm{m}, 2 \mathrm{H}, \mathrm{CH}_{2}\right), 1.46(\mathrm{~m}, 1 \mathrm{H}, \mathrm{CH}), 0.89\left(\mathrm{~m}, 6 \mathrm{H}, 2 \mathrm{CH}_{3}\right),{ }^{13} \mathrm{NMR}\left(\mathrm{CDCl}_{3}\right.$, $300 \mathrm{MHz}$ ): $\delta 169,168,156,134,127,126,120,66,45,37$; MS (EI) m/z: 330.16 (100.0\%), 331.16 (19.9\%), 332.16 (2.8\%). Anal. Calcd for $\mathrm{C}_{18} \mathrm{H}_{22} \mathrm{~N}_{2} \mathrm{O}_{4} ; \mathrm{C}, 65.44 ; \mathrm{H}, 6.71 ; \mathrm{N}, 8.48$; Found: C, 65.39, H, 6.83; N, 8.54.

(vi) N-Hydroxy-1-(2-(naphthalen-1-yloxy)acetyl)pyrrolidine2-carboxamide $\left(6_{\mathrm{f}}\right)$ : Yield: $0.94 \mathrm{gm}(30 \%)$ as a solid; $\mathrm{mp}$ 105-107 ${ }^{\circ} \mathrm{C}$. IR (KBr)m: 3300, 3050, $1650 \mathrm{~cm}^{-1},{ }^{1} \mathrm{H}$ NMR $\left(\mathrm{CDCl}_{3}, 300 \mathrm{MHz}\right)$ : $\delta$ 8.34-6.65 (m, 8H, Ar,1NH), $4.83\left(\mathrm{~s}, 2 \mathrm{H}, \mathrm{CH}_{2}\right), 4.22-2.54(\mathrm{~m}, 7 \mathrm{H}$, $\left.1 \mathrm{CH}, 3 \mathrm{CH}_{2}\right), 2.00(\mathrm{~s}, 1 \mathrm{H}, \mathrm{OH}) ;{ }^{13} \mathrm{NMR}\left(\mathrm{CDCl}_{3}, 300 \mathrm{MHz}\right): \delta 169,168$, $156,134,127,126,120,66,39123,127,120,67,45,29,21$; MS (EI) $\mathrm{m} / \mathrm{z}: 314.13$ (100.0\%), 315.13 (18.7\%), 316.13 (2.6\%):. Anal. Calcd for $\mathrm{C}_{17} \mathrm{H}_{18} \mathrm{~N}_{2} \mathrm{O}_{4} \mathrm{C}, 64.96 ; \mathrm{H}, 5.77 ; \mathrm{N}, 8.91$; Found C, 64.92, H, 5.96; N, 8.85.

(vii) N-Hydroxy-2-(2-(naphthalen-1-yloxy)acetamido)-3phenylpropanamide $\left(\mathbf{6}_{\mathrm{g}}\right)$ : Yield: $1.4 \mathrm{gm}(38 \%)$ as a solid; $\mathrm{mp}$ 132-135 ${ }^{\circ} \mathrm{C}$. IR (KBr)m: 3300, 3050, $1650 \mathrm{~cm}^{-1},{ }^{1} \mathrm{H}$ NMR $\left(\mathrm{CDCl}_{3}, 300 \mathrm{MHz}\right): \delta$ 8.34-6.65 (m, 14H, Ar,2NH), $4.92\left(\mathrm{~m}, 3 \mathrm{H}, \mathrm{CH}, \mathrm{CH}_{2}\right), 3.44-3.25(\mathrm{~m}$, $\left.2 \mathrm{H}, \mathrm{CH}_{2}\right), 2.00(\mathrm{~s}, 1 \mathrm{H}, \mathrm{OH}) ;{ }^{13} \mathrm{NMR}\left(\mathrm{CDCl}_{3}, 300 \mathrm{MHz}\right): \delta 169,168,158$, $134,133,127,126,125,124,120,107,67,49,37 ; \mathrm{MS}$ (EI) m/z: 364.14 (100.0\%), $365.15(23.1 \%), 366.15(3.4 \%))$. Anal. Calcd for $\mathrm{C}_{21} \mathrm{H}_{20} \mathrm{~N}_{2} \mathrm{O}_{4}$ : C, 69.22; H, 5.53; N, 7.69; Found C, 69.10, H, 5.45; N, 7.75.

(viii) N-Hydroxy-3-(4-hydroxyphenyl)-2-(2-(naphthalen-1yloxy)acetamido)propanamide $\left(\mathbf{6}_{\mathrm{h}}\right)$ : Yield: $1.2 \mathrm{gm}(31 \%)$ as a solid; mp 115-117 ${ }^{\circ} \mathrm{C}$. IR (KBr)m: 3300, 3050, $1650 \mathrm{~cm}^{-1},{ }^{1} \mathrm{H}$ NMR $\left(\mathrm{CDCl}_{3}\right.$, $300 \mathrm{MHz}): \delta 9.43(\mathrm{~s}, 1 \mathrm{H}, \mathrm{OH}), 8.31-6.65(\mathrm{~m}, 13 \mathrm{H}, \mathrm{Ar}, 2 \mathrm{NH}), 4.85$ (m, 3H, CH, $\mathrm{CH}_{2}$ ), 3.44-3.19 (m, $\left.2 \mathrm{H}, \mathrm{CH}_{2}\right), 2.00(\mathrm{~s}, 1 \mathrm{H}, \mathrm{OH}) ;{ }^{13} \mathrm{NMR}$ $\left(\mathrm{CDCl}_{3}, 300 \mathrm{MHz}\right): \delta 169,168,158,155,134,130,129,126,125,124$, 120, 115, 107, 67, 49, 37; MS (EI) m/z: 380.14 (100.0\%), 381.14 (23.1\%), 382.14 (3.7\%). Anal. Calcd for: $\mathrm{C}_{21} \mathrm{H}_{20} \mathrm{~N}_{2} \mathrm{O}_{5}: \mathrm{C}, 66.31 ; \mathrm{H}, 5.30$; N, 7.36; Found C, 66.20, H, 5.18; N, 7.45.

(ix) N-Hydroxy-3-(1H-indol-3-yl)-2-(2-(naphthalen-1-yloxy) acetamido)propanamide (6): Yield: 1 . gm $(25 \%)$ as a solid; mp 125 $127^{\circ} \mathrm{C}$. IR (KBr)m: 3300, 3050, $1650 \mathrm{~cm}^{-1},{ }^{1} \mathrm{H}$ NMR $\left(\mathrm{CDCl}_{3}, 300 \mathrm{MHz}\right)$ : $\delta 10.65(\mathrm{~s}, 1 \mathrm{H}, \mathrm{NH}), 8.31-6.65(\mathrm{~m}, 14 \mathrm{H}, \mathrm{Ar}, 2 \mathrm{NH}), 4.92(\mathrm{~m}, 3 \mathrm{H}, \mathrm{CH}$, $\left.\mathrm{CH}_{2}\right), 3.44-3.25\left(\mathrm{~m}, 2 \mathrm{H}, \mathrm{CH}_{2}\right), 2.00(\mathrm{~s}, 1 \mathrm{H}, \mathrm{OH}) ;{ }^{13} \mathrm{NMR}\left(\mathrm{CDCl}_{3}, 300\right.$ MHz): $\delta 168,158,134,127,126,124,120,118,111,109,107,67,49,27$; MS (EI) m/z: 403.15 (100.0\%), 404.16 (25.3\%), 405.16 (3.9\%), 404.15 (1.1\%). Anal. Calcd for : $\mathrm{C}_{23} \mathrm{H}_{21} \mathrm{~N}_{3} \mathrm{O}_{4}$ : C, $68.47 ; \mathrm{H}, 5.25 ; \mathrm{N}, 10.42$; Found C, $68.50, \mathrm{H}, 5.30 ; \mathrm{N}, 10.35$.

(x) N1-Hydroxy-2-(2-(naphthalen-1-yloxy)acetamido) succinamide $\left(6_{\mathrm{j}}\right)$ : Yield: $1.7 \mathrm{gm}(49 \%)$ as a solid; $\mathrm{mp} 120-123{ }^{\circ} \mathrm{C}$. IR (KBr)m: 3300, 3050, $1650 \mathrm{~cm}^{-1},{ }^{1} \mathrm{H}$ NMR $\left(\mathrm{CDCl}_{3}, 300 \mathrm{MHz}\right): \delta 8.31-6.65$ 
Citation: Abdelrahim AS, Mohan S, Albarrati M, Makeen H, Safhi MM (2016) Design, Synthesis, Molecular Modelling and Biological Evaluation of Novel a-Naphtholhydroxamate Derivatives as Potential Anticancer Agents. Med Chem (Los Angeles) 6: 682-689. doi:10.4172/21610444.1000415

(m, 10H, Ar,3NH), $4.92\left(\mathrm{~m}, 3 \mathrm{H}, \mathrm{CH}, \mathrm{CH}_{2}\right), 2.36\left(\mathrm{~m}, 4 \mathrm{H}, 2 \mathrm{CH}_{2}\right), 2.00$ $(\mathrm{s}, 1 \mathrm{H}, \mathrm{OH}) ;{ }^{13} \mathrm{NMR}\left(\mathrm{CDCl}_{3}, 300 \mathrm{MHz}\right): \delta 172,169,168,156,134,127$, $126,124,123,120,107,67,46,30$; MS (EI) m/z: $331.12(100.0 \%), 332.12$ (17.7\%), $333.12(2.7 \%), 332.11(1.1 \%)$. Anal. Calcd for: $\mathrm{C}_{16} \mathrm{H}_{17} \mathrm{~N}_{3} \mathrm{O}_{5}: \mathrm{C}$, $58.00 ; \mathrm{H}, 5.17 ; \mathrm{N}, 12.68$; Found C, 58.25, H, 5.05; N, 12.59 .

(xi) N1-Hydroxy-2-(2-(naphthalen-1-yloxy)acetamido) pentanediamide $\left(6_{\mathrm{k}}\right)$ : Yield: $1.5 \mathrm{gm}(43 \%)$ as a solid; $\mathrm{mp} 130-133{ }^{\circ} \mathrm{C}$. IR (KBr)m: 3300, 3050, $1650 \mathrm{~cm}^{-1},{ }^{1} \mathrm{H} \mathrm{NMR}\left(\mathrm{CDCl}_{3}, 300 \mathrm{MHz}\right): \delta 8.31-6.65$ $(\mathrm{m}, 10 \mathrm{H}, \mathrm{Ar}, 3 \mathrm{NH}), 4.92\left(\mathrm{~m}, 3 \mathrm{H}, \mathrm{CH}, \mathrm{CH}_{2}\right), 2.25\left(\mathrm{~m}, 4 \mathrm{H}, 2 \mathrm{CH}_{2}\right), 2.00(\mathrm{~s}$, $1 \mathrm{H}, \mathrm{OH}) ;{ }^{13} \mathrm{NMR}\left(\mathrm{CDCl}_{3}, 300 \mathrm{MHz}\right): \delta 173,169,168,156,134,127,126$, 124, 123, 120, 107, 67, 49, 32, 27; MS (EI) m/z: 345.13 (100.0\%), 346.14 (18.8\%), $347.14(2.7 \%), 346.13(1.1 \%)$. Anal. Calcd for: $\mathrm{C}_{17} \mathrm{H}_{19} \mathrm{~N}_{3} \mathrm{O}_{5}: \mathrm{C}$, $59.12 ; \mathrm{H}, 5.55 ; \mathrm{N}, 12.17$; Found C, 59.05, H, 5.45; N, 12.25 .

(xii) 4-(Hydroxyamino)-3-(2-(naphthalen-1-yloxy)acetamido)4-oxobutanoic acid (9): Yield: $1.4 \mathrm{gm}(42 \%)$ as a solid; $\mathrm{mp}$ 105-107 ${ }^{\circ} \mathrm{C}$. IR (KBr)m: 3300, 3050, $1650 \mathrm{~cm}^{-1},{ }^{1} \mathrm{H}$ NMR $\left(\mathrm{CDCl}_{3}, 300 \mathrm{MHz}\right): \delta$ $12.54(\mathrm{~s}, 1 \mathrm{H}, \mathrm{COOH}), 8.31-6.65(\mathrm{~m}, 9 \mathrm{H}, \mathrm{Ar}, 2 \mathrm{NH}), 4.92(\mathrm{~m}, 3 \mathrm{H}, \mathrm{CH}$, $\mathrm{CH} 2)$, 3.44-3.19 (m, $\left.2 \mathrm{H}, \mathrm{CH}_{2}\right), 2.00(\mathrm{~s}, 1 \mathrm{H}, \mathrm{OH}) ;{ }^{13} \mathrm{NMR}\left(\mathrm{CDCl}_{3}, 300\right.$ $\mathrm{MHz}): \delta 173,168,165,156,127,126,124,109,107,67,49,37$; MS (EI) m/z: 332.10 (100.0\%), 333.10 (18.0\%), 334.11 (2.7\%). Anal. Calcd for: $\mathrm{C}_{16} \mathrm{H}_{16} \mathrm{~N}_{2} \mathrm{O}_{6}: \mathrm{C}, 57.83 ; \mathrm{H}, 4.85 ; \mathrm{N}, 8.43$; Found C, 57.70, H, 5.90; N, 8.36.

(xiii) 5-(Hydroxyamino)-4-(2-(naphthalen-1-yloxy)acetamido)5-oxopentanoic acid $\left(\mathbf{9}_{\mathrm{b}}\right)$ : Yield: $1.7 \mathrm{gm}(49 \%)$ as a solid; $\mathrm{mp}$ 120-123 ${ }^{\circ} \mathrm{C}$. IR (KBr)m: 3300, 3050, $1650 \mathrm{~cm}^{-1},{ }^{1} \mathrm{H}$ NMR $\left(\mathrm{CDCl}_{3}, 300 \mathrm{MHz}\right): \delta$ $12.12(\mathrm{~s}, 1 \mathrm{H}, \mathrm{COOH}), 8.31-6.65(\mathrm{~m}, 9 \mathrm{H}, \mathrm{Ar}, 2 \mathrm{NH}), 4.92(\mathrm{~m}, 3 \mathrm{H}, \mathrm{CH}$, $\left.\mathrm{CH}_{2}\right), 2.25\left(\mathrm{~m}, 4 \mathrm{H}, 2 \mathrm{CH}_{2}\right), 2.00(\mathrm{~s}, 1 \mathrm{H}, \mathrm{OH}) ;{ }^{13} \mathrm{NMR}\left(\mathrm{CDCl}_{3}, 300 \mathrm{MHz}\right)$ : $\delta 176,168,156,134,127,126,124,107,67,30,26 ;$ MS (EI) m/z: 346.12 (100.0\%), 347.12 (18.8\%), 348.12 (3.0\%). Anal. Calcd for: $\mathrm{C}_{17} \mathrm{H}_{18} \mathrm{~N}_{2} \mathrm{O}_{6}$ : C, 58.96; H, 5.24; N, 8.09; Found C, 59.00, H, 5.30; N, 8.15.

\section{Biological evaluation}

Cell culture and cell viability: Hepg2, PC3, HT29, MCF 7, and WRL68 cells were obtained from ATTC. The RPMI-1640 medium, which is supplemented with $10 \%$ foetal bovine serum (FBS) and $1 \%$ penicillin and streptomycin were used in a humidified conditions at $5 \% \mathrm{CO}_{2}$ and $37^{\circ} \mathrm{C}$.

MTT assay has been used to measure the viability of percentage of cells upon treatments with various compounds under investigation [18]. Briefly, cells $\left(5 \times 10^{4}\right.$ cells $\left./ \mathrm{ml}\right)$ were treated with compounds at different concentration in 96-well plate and incubated for $24 \mathrm{~h}$. Compounds were then diluted in various concentrations and treated for another 24 hours. The end point colour developed was measured and recorded at absorbance of $570 \mathrm{~nm}$ using Eliza reader. Raw data of absorbance were used to calculate results which were expressed as percentage of control giving percentage cell viability after $24 \mathrm{~h}$ exposure to test agent. The potency of cell growth inhibition for test agent was expressed as $\mathrm{IC}_{50}$ value.

Intracellular ROS level: Since the compound $\mathbf{6}_{\mathrm{g}}$ and $\mathbf{6}_{\mathrm{h}}$ were exhibited significant cytotoxicity, only these compounds were used to detect the level of ROS in HepG2 cells. 2',7'-dichlorluorescin diacetate (DCFH-DA) was used to measure the production of intracellular ROS according to reported procedure [19]. In brief, DCFH-DA stock solution $(10 \mathrm{mM})$ was diluted 500-fold in Hank's Balanced Salt Solution (HBSS) to yield a working solution of $20 \mu \mathrm{M}$. After $24 \mathrm{~h}$ of exposure to compounds the cells in the 96- well black plate was washed twice with HBSS and then incubated in $100 \mu$ l working solution of DCFH$\mathrm{DA}$ at $37^{\circ} \mathrm{C}$ for $30 \mathrm{~min}$. Fluorescence was then determined at $485-\mathrm{nm}$ excitation and $520 \mathrm{~nm}$ emission using a fluorescence microplate reader.
Hemolytic assays: The interaction between the synthesized compounds $\mathbf{6}_{\mathrm{g}}, \mathbf{6}_{\mathrm{h}}$ and $\mathbf{6}_{\mathrm{k}}$ with erythrocyte membranes was investigated using hemolytic experiments. Hemolysis was used to quantify the membrane-damaging properties of compounds $\mathbf{6}_{\mathrm{g}}, \mathbf{6}_{\mathbf{h}}$ and $\mathbf{6}_{\mathrm{k}}$. Human erythrocytes were isolated from fresh heparin-treated blood collected from healthy adult volunteers by centrifugation at $3000 \mathrm{rpm}$ for $15 \mathrm{~min}$ (Sigma 2-5 centrifuge, Sigma Laborzentrifugen GmbH, Osterode am Harz, Germany). The pellet was washed four times with an isotonic phosphate buffer saline (PBS) at $\mathrm{pH} 7.4$, centrifuged at $3000 \mathrm{rpm}$ for $15 \mathrm{~min}$ and resuspended in the same buffer. The erythrocyte pellet was diluted in PBS at $\mathrm{pH} 7.4$ to a final concentration of $4 \%(\mathrm{v} / \mathrm{v})$ erythrocytes. This stock solution was always freshly prepared and used within $24 \mathrm{~h}$.

Compounds $\mathbf{6}_{\mathrm{g}}, \mathbf{6}_{\mathrm{h}}$ and $\mathbf{6}_{\mathrm{k}}$ were prepared in PBS at different concentrations $(0.1,0.5,1,5$ and $10 \mathrm{mM})$ and transferred to 96 -well flat-bottom microtiter plates (TPP, Zurich, Switzerland). The plates were then incubated at $37^{\circ} \mathrm{C}$ for $60 \mathrm{~min}$ on a Titramax 1000 Vibrating Shaker (Heidolph, Schwabach, Germany). Erythrocyte suspensions $(100 \mu \mathrm{l})$ were added to each well on the plate and incubated for $60 \mathrm{~min}$ at $37^{\circ} \mathrm{C}$ with constant shaking. After centrifugation at $3000 \mathrm{rpm}$ for $15 \mathrm{~min}$, the release of hemoglobin was determined by photometric analysis of the supernatant at $540 \mathrm{~nm}$. Complete hemolysis was achieved by using $10 \mathrm{mM}$ of sodium dodecyl sulfate (SDS) in PBS as a positive control (100\%), while PBS was used as a negative control. Each experiment was performed in triplicate. The percentage of hemolysis was calculated according to the following formula:

$$
\% \text { lysis }=\left[\frac{\mathrm{A}_{\text {test }}-\mathrm{A}_{\text {blank }}}{\mathrm{A}_{100 \% \text { lysis }}-\mathrm{A}_{\text {blank }}}\right] \times 100
$$

where $A_{\text {test }}$ is the absorbance value of the hemoglobin released from erythrocytes treated with the test compounds; $A_{\text {blank }}$ is the absorbance value of the hemoglobin released from erythrocytes treated with PBS buffer, and $\mathrm{A}_{100 \% \text { lysis }}$ is the absorbance value of the hemoglobin released from erythrocytes treated with $10 \mathrm{mmol}$ SDS in PBS solution [20].

\section{Molecular docking studies}

Molecular docking studies were carried out using AutoDock 4.2 [21] tool to predict the preferred binding mode and binding sites of synthesized compounds with the crystal structure of the HDAC8. The structures of the synthesized compounds were drawn using $\mathrm{ACD} /$ ChemSketch and its geometry was optimized by combine use of Gaussian 03 program and Autodock 4.2. The crystal structure of HDAC8 (PDB ID: 1T69) was obtained from Protein Data Bank, www.rcsb.org/pdb/home/home.do. Before docking analysis Hetatm were removed from the protein and the energy was minimized using SPDBV-Swiss-pdbviewer. For docking calculations, the receptor file prepared with the addition of polar hydrogens, Kollman charges, and solvation parameters. The precalculated grid maps set at the size set at 60,60 , and $60 \mathrm{~A}^{\circ}(\mathrm{x}, \mathrm{y}$, and $\mathrm{z})$ to include all the amino acid residues that present in the receptor. The spacing between grid points was 0.575 angstroms. The Lamarckian genetic algorithm (LGA) chosen to confirm maximum of 10 conformers was considered to the docking process with the population size of 150 individuals. The output from AutoDock was further analyzed with PyMOLoftware package [9].

\section{Results and Discussion}

\section{Chemistry}

The newly synthesized compounds were designed by joining two different moieties as mentioned in Scheme 1. $\alpha$-Naphthol was reacted with chloroacetic acid to afford 2-(naphthalen-1-yloxy)acetic acid 3 
Citation: Abdelrahim AS, Mohan S, Albarrati M, Makeen H, Safhi MM (2016) Design, Synthesis, Molecular Modelling and Biological Evaluation of Novel a-Naphtholhydroxamate Derivatives as Potential Anticancer Agents. Med Chem (Los Angeles) 6: 682-689. doi:10.4172/21610444.1000415

and subsequent reacted with amino acid methyl ester hydrochloride derivatives to give the corresponding compounds $\mathbf{5}_{(\mathrm{a}-\mathrm{m}) .}$. The obtained derivatives were reacted with hydroxyl amine hydrochloride in freshly distilled methanol to prevent any moisture that harms the presence of ester with potassium hydroxide. Also, the reaction was accomplished at room temperature to prevent also ester hydrolysis. By exploiting this technique, the yield was satisfactory (Scheme 1).

Also, aspartic and glutamic acids were used to synthesis compounds bearing two hydroxamate moieties to examine the effect of two hydroxamate moieties on the biological activities as in Scheme 2.

\section{Biological evaluation}

Cell culture and cell viability: In vitro cell assay is the best method to screen the ability of synthetic compounds against various cancers. Using these cells, many cytotoxicity assays has been developed. The significant one is the colorimetric MTT assay, which is based on the assumption that dead cells or their products do not reduce tetrazolium [22]. The assay depends both on the number of cells present and on the mitochondrial activity per cell. In the current study, the cytotoxicity of the synthesized compounds were studied using the MTT assay in four human cancer cell lines, including Hepg2, PC3, HT29, MCF 7, and WRL68. The results are listed in Table 1.

The different cell lines were selected due to some considerations. i) Hepatocellular carcinoma (HCC) is now the third leading cause of cancer deaths worldwide, with over 500,000 people affected. The incidence of HCC is highest in Asia and Africa, where the endemic high prevalence of hepatitis B and hepatitis $\mathrm{C}$ strongly predisposes to the development of chronic liver disease and subsequent development of HCC [23]. ii) The selected cell lines cover the most common cancer diseases.

Among the compounds, compound $\mathbf{6}_{\mathrm{g}}$ had exhibited significant cytotoxicity against almost all the used cells including the normal cells. The next significant compound which showed cytotoxicity was compound $\mathbf{6}_{i}$ that showed significant cytotoxicity against almost all the used cells including the normal cells but less than compound $\mathbf{6}_{\mathrm{g}}$. Compound $\mathbf{6}_{\mathrm{b}}$ was showed cytotoxicity to Hepg2 cells alone with an $\mathrm{IC}_{50}$ of $7.1 \pm 0.4 \mu \mathrm{M}$.

Intracellular ROS level: The cell death and ROS generation is closely associated [24]. Reactive oxygen species (ROS) are emerging as critical signalling molecules. The term reactive oxygen species encompasses a wide range of molecules. Free radicals are chemical species containing one or more unpaired electrons [25]. Therapeutic strategies that promote ROS accumulation and cell death have been explored based on the availability of drugs that interfere with scavenging. Hence the Intracellular ROS was measured in HepG2 cells with 10 and $20 \mu \mathrm{g} / \mathrm{ml}$ concentrations of compound $\mathbf{6}_{\mathrm{g}}$ and $\mathbf{6}_{\mathrm{h}}$. As the Figure $1 \mathrm{~A}$ and $1 \mathrm{~B}$ showed both the compounds has exhibited significant increase in the level of ROS in concentration dependent manner in treated cells (Figure 2).

Hemolytic assay: The release of hemoglobin was used to quantify the membrane damaging properties of the synthesized compounds. Erythrocytes were treated with PBS and SDS to obtain values corresponding to 0 and $100 \%$ of lysis, respectively [25]. The erythrocytes were incubated for $1 \mathrm{~h}$ with five different concentrations $\left(0.1,0.5,1,5\right.$ and $10 \mathrm{mM}$ of compounds $\mathbf{6}_{\mathrm{g}}, \mathbf{6}_{\mathrm{h}}$ and $\mathbf{6}_{\mathrm{k}}$ to measure hemolyticlysis. Only compound $\mathbf{6}_{\mathrm{g}}$ with higher concentration $(10 \mathrm{mM}$ showed significant hemolysis due to higher lipophilicity characteristics. while compounds $\mathbf{6}_{\mathrm{h}}$ and $\mathbf{6}_{\mathrm{k}}$ caused almost no hemolysis $(\leq 10 \%)$ even in higher concentration. These results correlate with our prediction using mollinspiration data base.

\section{Molecular docking studies}

In order to get preliminary information on the binding mode of these compounds to HDAC, we selected three representative compounds, $\mathbf{5}_{\mathrm{g}}$, $\mathbf{5}_{b}$, and $\mathbf{6}_{k}$ which showing the highest affinity for docking study. Since crystal structures of HDAC3 and HDAC4 in complex with SAHA have not been determined so far, we used the crystal structure of HDAC8 in complex with SAHA which shows sequence similarity (46\%) to HDAC4 [1], for docking experiments of compound $\mathbf{5}_{\mathrm{g}}, \mathbf{5}_{\mathrm{h}}$, and $\mathbf{6}_{\mathbf{k}}$. We implemented control docking experiments with SAHA to the crystal structure of HDAC8 using AutoDock program [26,27].

The proposed binding mode of compound $\left(\mathbf{6}_{\mathrm{g}}\right)$ is that the phenyl ring of the compound $6 \mathrm{~g}$ is involved in aromatic stacking interactions with Phe152, His143, His180, His208, and Tyr306. The two amino groups of the compound is involved in a hydrogen bonding interaction with Asp101. The bicyclic moiety of the compound is involved in aromatic stacking interactions with Tyr 100 and Tyr306 and is located in the hydrophobic pocket formed by Ile34, lyophobic part of Lys33, and Met274 (Figure 3), and because of the existence of additional hydrogen bonding, desirable interactions, and can nicely fit into the binding site, compound $\left(\mathbf{6}_{q}\right)$ has the highest affinity towards the receptor than other compounds showing anticancer activity towards Hepg-2, PC-3, HT-

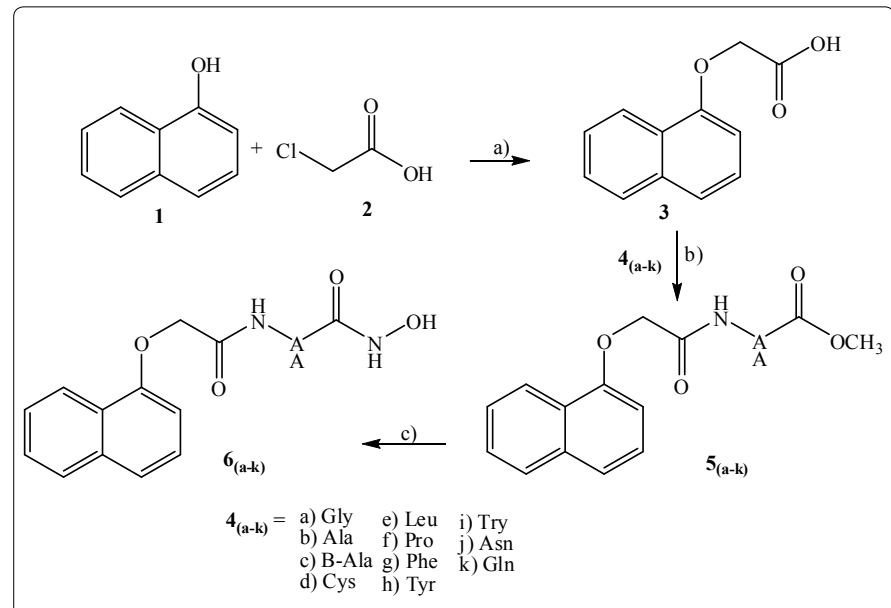

Scheme 1: Reagents and conditions: a) $\mathrm{K}_{2} \mathrm{CO}_{3}$, acetone $70^{\circ} \mathrm{C}, 12 \mathrm{~h}$; b) (i) $\mathrm{SOCl}_{2}$, $\mathrm{DCM}$, reflux $3 \mathrm{~h}$, rt, (ii) amino acid methyl ester hydrochloride 4, TEA, DCM, rt, 24 h; c) $\mathrm{NH}_{2} \mathrm{OH}, \mathrm{KOH}, \mathrm{CH}_{3} \mathrm{OH}, \mathrm{rt}, 12 \mathrm{~h}$.

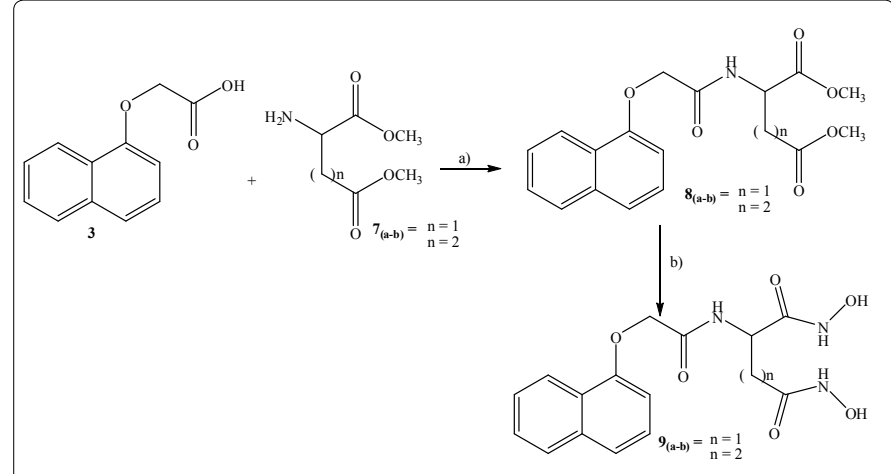

Scheme 2: Reagents and conditions: a) (i) $\mathrm{SOCl}_{2}, \mathrm{DCM}$, reflux $3 \mathrm{~h}$, rt, (ii) amino acid methyl ester hydrochloride 7, TEA, DCM, rt, $24 \mathrm{~h}$; b) $\mathrm{NH}_{2} \mathrm{OH}, \mathrm{KOH}, \mathrm{CH}_{3} \mathrm{OH}$, rt, $12 \mathrm{~h}$. 
Citation: Abdelrahim AS, Mohan S, Albarrati M, Makeen H, Safhi MM (2016) Design, Synthesis, Molecular Modelling and Biological Evaluation of Novel a-Naphtholhydroxamate Derivatives as Potential Anticancer Agents. Med Chem (Los Angeles) 6: 682-689. doi:10.4172/21610444.1000415

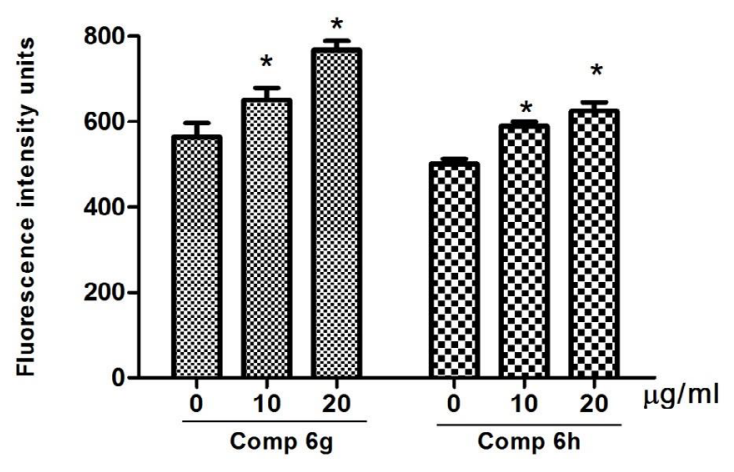

Figure 2: Effects of Compound $6 \mathrm{~g}$ and $6 \mathrm{~h}$ on HepG2 cells ROS generation. DCF-fluorescence intensity after 10 and $20 \mu \mathrm{g} / \mathrm{ml}$ of exposure at $24 \mathrm{~h}$. Values are mean $\pm S D$ from three independent experiments. Triplicates of each treatment group were used in each independent experiment. The Statistical significance is expressed as ${ }^{*} \mathrm{P}<0.05$.

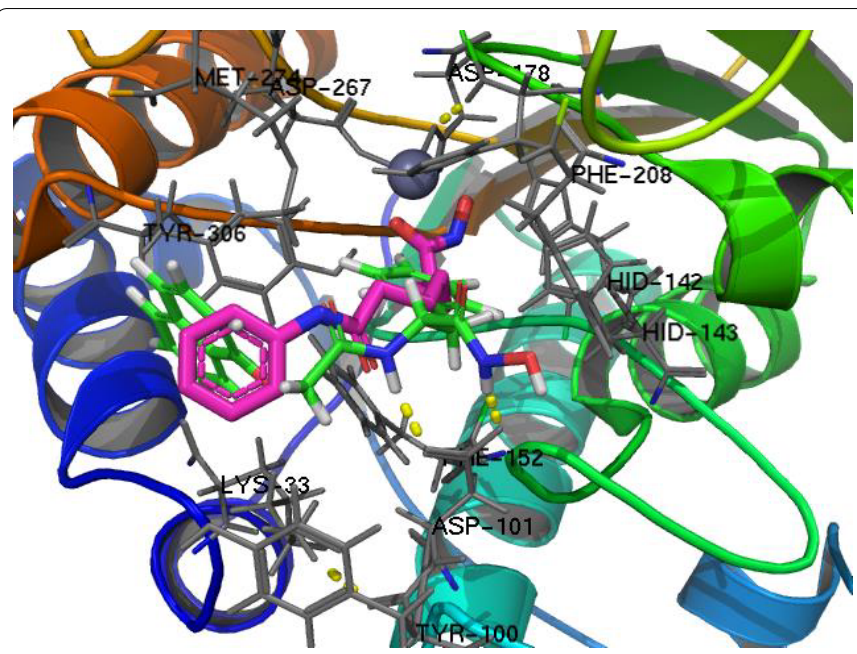

Figure 3: Predicted binding modes of compound $\mathbf{6}_{\mathrm{g}}$ to HDAC8. The actual binding pose of SAHA to HDAC8 is shown as a stick model with carbon colored in magenta, and compound $6 \mathrm{~g}$ colored in green. Nitrogen in blue, and oxygen in red. The important residues for the interaction are colored in gray. Other atoms are colored same as $\mathrm{Zn}^{2+}$ ion is shown as a dark gray sphere.

29, MCF-7 and WRL-68 cell lines with IC $_{50}$ value of 8.2, 16.1, 14.3, 13.6 and $6.5 \mu \mathrm{gM}$, respectively.

On the other hand, compound $\left(\mathbf{6}_{\mathrm{h}}\right)$ exhibited promising anticancer activity towards Hepg-2, PC-3, HT-29, MCF-7 and WRL-68 cell lines with $\mathrm{IC}_{50}$ value of $9,12.1,49.0$, and $61.0 \mu \mathrm{g} / \mathrm{ml}$, respectively. Thus, introduction of hydroxyl group attached with the phenyl moiety of the compound $\left(\mathbf{6}_{\mathrm{h}}\right)$ is likely important for increasing the affinity for the receptor. The obtained result for compound $\left(\mathbf{6}_{\mathrm{h}}\right)$ is virtually the same as that of compound $\left(\mathbf{6}_{\mathrm{g}}\right)$. In addition, the hydroxyl group is stabilized by a hydrogen bonding interaction with Tyr306. However, the one amino group is only involved in a hydrogen bonding interactions Asp101 which can decrease the affinity for the receptor (Figure 4).

Whereas, compound $\left(\mathbf{6}_{\mathrm{i}}\right)$ exhibited significant anticancer activity towards WRL-68, Hepg-2, MCF-7, PC-3, and HT-29 cell lines with IC value of $7.1,20.6,21.2,18.0$, and $9.0 \mu \mathrm{M}$, respectively. The obtained results were explained and confirmed by docking modeling data where, the obtained binding mode of compound $\left(\mathbf{6}_{\mathbf{k}}\right)$ with the binding site of HDAC8 follows the general pattern observed for compound $\left(\mathbf{6}_{\mathrm{g}}\right)$. As before, the hydrogen bonding interactions and aromatic stacking interactions are maintained. However, insertion of indole moiety of the compound $\mathbf{6}_{\mathbf{i}}$ could abolish aromatic stacking interaction with Tyr100 which is essential for ligand affinity. Furthermore, due to desirable interactions compound cannot accommodate the binding site (Figure 5).

\section{ADME profiling}

The bioavailability of these compounds can be predicted using mipc-Molinspiration Property Calculator [28]. In particular, we calculated the compliance of compounds to Lipinski's "rule of five" to evaluate the drug-likeness [29]. The rule describes molecular properties which are important for drug's pharmacokinetics in the human body, including their absorption, distribution, metabolism and elimination (ADME) and it is used to make sure that drug like physicochemical properties are maintained during drug design. This simple rule states that orally active drug has no more than one violation of the following criteria: molecular weight less than 500 Dalton; no more than five hydrogen bond donors; no more than 10 hydrogen bond acceptors; and calculated octanol-water partition coefficient (mlogP) not greater than 5 [30]. Moreover, topological polar surface area (TPSA) together with the number of rotatable bonds have been considered to be very good descriptors of oral bioavailability of drugs. Compounds which meet the following two criteria: ten or fewer rotatable bonds and polar surface area equal to or less than $140 \AA^{2}$ are predicted to exhibit good oral bioavailability. The calculated parameters presented in Table showed good bioavailability of studied compounds.

The most active compounds $\mathbf{6}_{\mathrm{g}}, \mathbf{6}_{\mathrm{h}}$ and $\mathbf{6}_{\mathbf{k}}$ fulfilled all rules. Theoretically, these three compounds should exhibit good passive oral absorption and differences in their bioactivity cannot be attributed to these properties. Also, the determined $\log P$ values were 2.84, 2.36 and 0.31 respectively, which affirmed the hydrophilic-lipophilic balance of compounds $\mathbf{6}_{\mathrm{g}}$ and $\mathbf{6}_{\mathrm{h}}$ while compound $\mathbf{6}_{\mathbf{k}}$ is more hydroophilic and consequently more water solubility (Table 2 ).

\section{SAR}

Observing the results, we could deduce valuable data about the structure activity relationships. Firstly, we explored the effect of amino acid linkers. The decreased $\mathrm{IC}_{50}$ values of compounds $\mathbf{6}_{\mathbf{f}}, \mathbf{6}_{\mathbf{g}}, \mathbf{6}_{\mathrm{i}}$, and $\mathbf{6}_{\mathrm{j}}$ with incorporated Phe, Tyr and Gln moieties, respectively than those of their corresponding members indicated that substitution with Phe, Tyr and Gln is advantageous.

We then investigated the impact of the substitution with two hydroxamate moieties. It was found that the insertion of two hydroxamate moieties is more preferred biologically. Moreover, the substitution with glutamate moiety is more advantageous than that of aspartate one

\section{Conclusion}

To sum up, in the present study we have described a straightforward and efficient synthesis of thirteen novel hybrid compounds containing hydroxamate moiety with $\alpha$-naphthol amino acid conjugates, starting from simply prepared $\alpha$-naphthol amino acid esters. The biological activities and structure-activity relationships (SARs) of the newly synthesized compounds were evaluated. Using hydroxamic acid with potassium hydroxide at room temperature for long period was found beneficial than using potassium hydroxide with heating because it hydrolyzed amino acid ester before the reaction. In Addition using different derivatives of amino acids (lipophilic and hydrophilic) helps us to study structure activity relationships of these derivatives and 
Citation: Abdelrahim AS, Mohan S, Albarrati M, Makeen H, Safhi MM (2016) Design, Synthesis, Molecular Modelling and Biological Evaluation

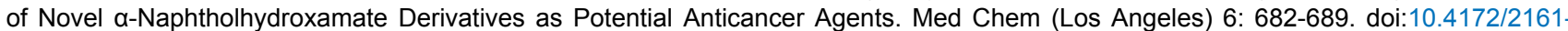
0444.1000415

\begin{tabular}{|c|c|c|c|c|c|c|}
\hline \multirow{2}{*}{ Comp. } & \multicolumn{5}{|c|}{$\mathrm{IC}_{50}(\mu \mathrm{M})^{\mathrm{a}}$} & \multirow{2}{*}{$\underset{\mathrm{kcal} / \mathrm{mol}}{\Delta \mathbf{G}^{\mathrm{c}}}$} \\
\hline & HePG2 & PC3 & HT29 & MCF-7 & WRL68 & \\
\hline 6 & $\mathrm{NA}^{\mathrm{b}}$ & $\mathrm{NA}^{\mathrm{b}}$ & $N A^{b}$ & $N A^{b}$ & $N A^{b}$ & -20.91 \\
\hline $6_{b}$ & $N A^{b}$ & $N A^{b}$ & $N A^{b}$ & $N A^{b}$ & $81.6 \pm 1.1$ & -30.30 \\
\hline $6_{c}$ & $11.7 \pm 1.3$ & $22.0 \pm 1.9$ & $40.8 \pm 2.71$ & $21.6 \pm 2.8$ & $11.2 \pm 1.1$ & -30.17 \\
\hline $6_{d}$ & $12.8 \pm 1.4$ & $29.9 \pm 1.5$ & $43.6 \pm 2.4$ & $22.5 \pm 1.7$ & $9.2 \pm 1.3$ & -30.23 \\
\hline $6_{e}$ & $\mathrm{NA}^{\mathrm{b}}$ & $\mathrm{NA}^{\mathrm{b}}$ & $N A^{b}$ & $\mathrm{NA}^{\mathrm{b}}$ & $15.6 \pm 5.3$ & -40.89 \\
\hline $6_{f}$ & $15.8 \pm 1.5$ & $30.0 \pm 1.6$ & $45.0 \pm 1.1$ & $30.8 \pm 1.9$ & $12.5 \pm 2.2$ & -30.72 \\
\hline $6_{g}$ & $8.2 \pm 1.1$ & $16.1 \pm 1.3$ & $14.3 \pm 0.8$ & $13.6 \pm 1.1$ & $6.5 \pm 2.3$ & -50.92 \\
\hline $6_{h}$ & $7.1 \pm 0.4$ & $20.6 \pm 1.7$ & $21.2 \pm 1.2$ & $18.0 \pm 0.9$ & $9.0 \pm 1.2$ & -50.84 \\
\hline 6 & $7.8 \pm 0.7$ & $21.4 \pm 1.3$ & $19.2 \pm 1.3$ & $16.8 \pm 3.6$ & $4.6 \pm 1.2$ & -50.36 \\
\hline $6_{j}$ & $15.6 \pm 1.7$ & $28.4 \pm 1.1$ & $N A^{b}$ & $44.8 \pm 2.7$ & $5.9 \pm 4.3$ & -40.48 \\
\hline $6_{k}$ & $16.9 \pm 2.0$ & $26.3 \pm 3.1$ & $46.8 \pm 1.7$ & $26.3 \pm 1.7$ & $8.7 \pm 3.1$ & -50.07 \\
\hline $9_{\mathrm{a}}$ & $29.1 \pm 1.4$ & $16.9 \pm 1.3$ & $N A^{b}$ & $30.3 \pm 1.3$ & $19.4 \pm 2.2$ & -40.61 \\
\hline $9_{b}$ & $24.1 \pm 0.9$ & $26.3 \pm 1.8$ & $33.2 \pm 0.1$ & $27.7 \pm 2.3$ & $15.0 \pm 4.2$ & -40.61 \\
\hline Doxo $^{d}$ & $5.76 \pm 0.4$ & $8.22 \pm 1.2$ & $6.13 \pm 2.0$ & $7.73 \pm 1.1$ & $4.54 \pm 1.4$ & $\mathbf{N} \mathbf{T}^{\mathrm{f}}$ \\
\hline $\mathrm{SHH}^{\mathrm{e}}$ & $N T^{f}$ & $\mathbf{N} \mathbf{T}^{\mathrm{r}}$ & $N T^{f}$ & $\mathbf{N} \mathbf{T}^{\mathrm{r}}$ & $N T^{f}$ & -55.23 \\
\hline
\end{tabular}

${ }^{a} C_{50}$ values are the mean $\pm \mathrm{SD}$ of three separate experiments; ${ }^{\mathrm{N} A} \mathrm{~A}$ : Compounds having $\mathrm{IC}_{50}$ value $>50 \mu \mathrm{M}$; ' $\mathrm{Docking}$ energy scores; ${ }^{\mathrm{d}}$ Doxo: Doxorubicin; e $\mathrm{SHH}$ : cocrystallized ligand (Octanedioic acid hydroxyamidephenylamide); ${ }^{\mathrm{f}} \mathrm{NT}$ : Compounds not tested.

Table 1: $I C_{50}$ values of compounds in selected cell lines assessed by MTT assay.

\begin{tabular}{|c|c|c|c|c|c|c|c|}
\hline Comp. & MW & $\begin{array}{c}\text { No. of } \\
\text { H-bond donors }\end{array}$ & $\begin{array}{c}\text { No. of } \\
\text { H-bond acceptors }\end{array}$ & milogP & $\begin{array}{l}\text { No. of rotatable } \\
\text { bonds }\end{array}$ & TPSA & No. of violation \\
\hline 6 & 274.28 & 3 & 6 & 1.05 & 5 & 87.66 & 0 \\
\hline $6 b_{b}$ & 288.30 & 3 & 6 & 1.38 & 5 & 87.66 & 0 \\
\hline 6 c & 288.30 & 3 & 6 & 1.32 & 6 & 87.66 & 0 \\
\hline $6 \mathrm{~d}$ & 320.37 & 3 & 6 & 1.36 & 6 & 87.66 & 0 \\
\hline $6_{e}$ & 330.38 & 3 & 6 & 2.69 & 7 & 87.66 & 0 \\
\hline $6_{f}$ & 314.34 & 2 & 6 & 1.68 & 4 & 78.87 & 0 \\
\hline $6 g$ & 364.40 & 3 & 6 & 2.84 & 7 & 87.66 & 0 \\
\hline $6 b_{h}$ & 380.40 & 4 & 7 & 2.36 & 7 & 107.89 & 0 \\
\hline $6_{i}$ & 403.44 & 4 & 7 & 2.99 & 7 & 103.45 & 0 \\
\hline $6_{j}$ & 331.33 & 5 & 8 & 1.26 & 7 & 130.75 & 0 \\
\hline $6_{k}$ & 345.36 & 5 & 8 & 0.31 & 8 & 130.75 & 0 \\
\hline $9_{\mathrm{a}}$ & 347.33 & 5 & 9 & 1.32 & 7 & 136.98 & 0 \\
\hline $9_{b}^{a}$ & 361.35 & 5 & 9 & 0.37 & 8 & 136.98 & 0 \\
\hline
\end{tabular}

MW: Molecular weight; milogP: Octanol-water partition coefficient (logP predicted at Molinspiration); TPSA: Topological polar surface area

Table 2: ADME of synthesized compounds $6_{a-k}$ and $9_{a-b}$ using Molinspiration property calculator.

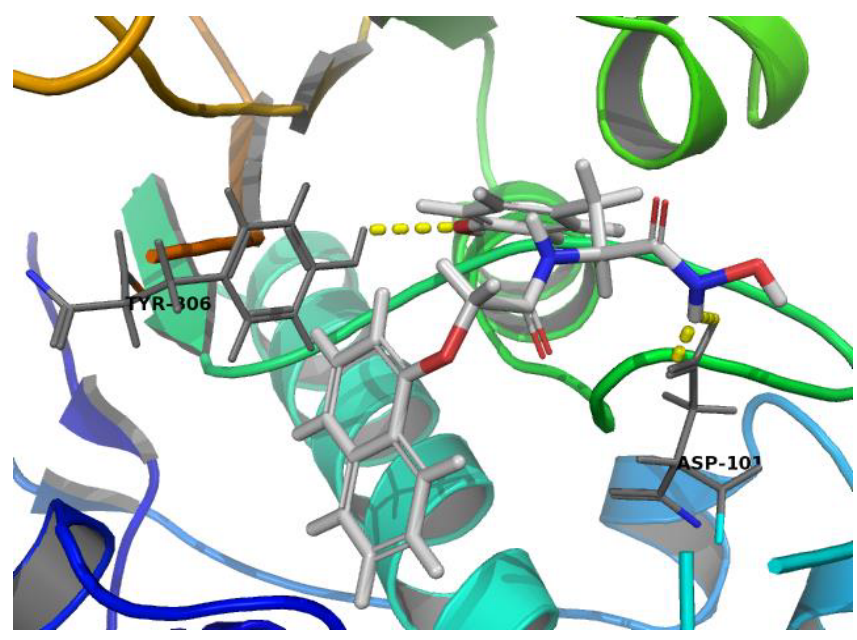

Figure 4: Predicted binding modes of compound 6 to HDAC8. The actual binding pose of 6 to HDAC8 is shown as a stick model with carbon colored in grey. Nitrogen in blue, and oxygen in red.
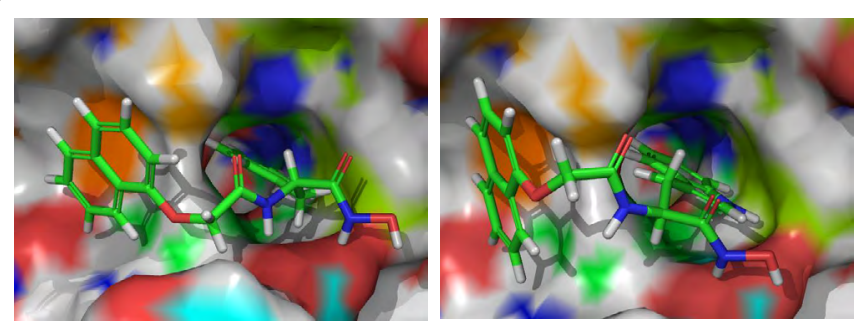

Figure 5: View of surface and active site of compounds 6 and 6 bound to HDAC8. Compound $\left(6_{\mathrm{g}}\right)$ can fit nicely inside the binding pocket.

encouraged us to make more modification to find out more effective and safer derivatives. The docking studies also supported the results concluded from the anti-proliferation screening. The results of this study may find a lead toward the development of new therapeutic agent to fight cancer. But all these findings support the need for further investigations such as molecular optimization, enzymatic assay and in vivo studies of more effective compound may be considered a future plan for producing effective and safer anticancer agents. 
Citation: Abdelrahim AS, Mohan S, Albarrati M, Makeen H, Safhi MM (2016) Design, Synthesis, Molecular Modelling and Biological Evaluation of Novel a-Naphtholhydroxamate Derivatives as Potential Anticancer Agents. Med Chem (Los Angeles) 6: 682-689. doi:10.4172/21610444.1000415

\section{Acknowledgements}

The authors wish to express their thanks to Dr. Mohamed Elsafhi, Dean of the Faculty of Pharmacy, Jazan University for his help.

\section{References}

1. Panneerselvam $P$, Nair RR, Vijayalakshmi G, Subramanian $E H$, Sridhar SK (2005) Synthesis of schiff bases of 4-(4-aminophenyl)-morpholine as potential antimicrobial agents. European journal of medicinal chemistry 40: 225-229.

2. Gomez CM, Kouznetsov V (2013) Recent developments on antimicrobial quinoline chemistry. Formatex 1: 666-677.

3. Van Beusichem M, Farrell N (1992) Activation of the trans geometry in platinum antitumor complexes. Synthesis, characterization, and biological activity of complexes with the planar ligands pyridine, n-methylimidazole, thiazole, and quinoline, Crystal and molecular structure of trans-dichlorobis (thiazole) platinum (iii). Inorganic Chemistry 31: 634-639.

4. Baba A, Kawamura N, Makino H, Ohta Y, Taketomi S, et al. (1996) Studies on disease-modifying antirheumatic drugs: Synthesis of novel quinoline and quinazoline derivatives and their anti-inflammatory effect 1 . Journal of medicinal chemistry 39: 5176-5182.

5. Kadin SB (1978) 1-oxo-6-substituted pyrimido [1, 2-a] quinoline-2-carboxylic acids and derivatives thereof and their use as antiallergy agents. Google Patents US4066766 A, USA.

6. Tai Y, Landesman Y, Acharya C, Calle Y, Zhong M, at al. (2014) Crm1 inhibition induces tumor cell cytotoxicity and impairs osteoclastogenesis in multiple myeloma: Molecular mechanisms and therapeutic implications. Leukemia 28 155-165.

7. Sun Q, Carrasco YP, Hu Y, Guo X, Mirzaei H, et al. (2013) Nuclear export inhibition through covalent conjugation and hydrolysis of leptomycin b by crm1. Proceedings of the National Academy of Sciences 110: 1303-1308.

8. Bano S, Alam MS, Javed K, Dudeja M, Das AK, et al. (2015) Synthesis, biological evaluation and molecular docking of some substituted pyrazolines and isoxazolines as potential antimicrobial agents. European journal of medicinal chemistry 95: 96-103

9. Momose Y, Maekawa T, Yamano T, Kawada M, Odaka H, et al. (2002) Novel 5-substituted 2, 4-thiazolidinedione and 2, 4-oxazolidinedione derivatives as insulin sensitizers with antidiabetic activities. Journal of medicinal chemistry 45: 1518-1534.

10. Etchin J, Sanda T, Mansour MR, Kentsis A, Montero J, et al. (2013) Kpt-330 inhibitor of crm1 (xpo1)-mediated nuclear export has selective anti-leukaemic activity in preclinical models of t-cell acute lymphoblastic leukaemia and acute myeloid leukaemia. British journal of haematology 161: 117-127.

11. Zhang K, Wang M, Tamayo AT, Shacham S, Kauffman M, et al. (2013) Nove selective inhibitors of nuclear export crm1 antagonists for therapy in mantle cell lymphoma. Experimental hematology 41: 67-78.

12. Pearce BC, Wright JJ (1995) Antihyperlipidemic/antioxidant dihydroquinolines. Google Patents US5411969 A, Bristol-Myers Squibb Company, USA.

13. Muruganantham N, Sivakumar R, Anbalagan N, Gunasekaran V, Leonard JT (2004) Synthesis, anticonvulsant and antihypertensive activities of 8-substituted quinoline derivatives. Biological and Pharmaceutical Bulletin 27: 1683-1687.

14. Edmont D, Rocher R, Plisson C, Chenault J (2000) Synthesis and evaluation of quinoline carboxyguanidines as antidiabetic agents. Bioorganic and medicinal chemistry letters 10: 1831-1834

15. Katsuhik H, Kiyoshi OF (1980) 4-phenyl-2-(1-piperazinyl) quinolines with potent antidepressant activity. Chem Pharm Bull 28: 2618-2622.

16. Sridhar R, Perumal PT, Etti S, Shanmugam G, Ponnuswamy MN, et al. (2004) Design, synthesis and anti-microbial activity of $1 \mathrm{~h}$-pyrazole carboxylates. Bioorganic and medicinal chemistry letters 14: 6035-6040.

17. Musad EA, Mohamed R, Saeed BA, Vishwanath BS, Rai LK (2011) Synthesis and evaluation of antioxidant and antibacterial activities of new substituted bis (1, 3, 4-oxadiazoles), 3, 5-bis (substituted) pyrazoles and isoxazoles. Bioorganic and medicinal chemistry letters 21: 3536-3540.

18. Giske CG, Cornaglia G, Goar ES (2010) Surveillance; Supranational surveillance of antimicrobial resistance: The legacy of the last decade and proposals for the future. Drug Resistance Updates 13: 93-98.
19. Rodriguez G (1999) A cohort study on the risk of acute liver injury among users of ketoconazole and other antifungal drugs. British journal of clinical pharmacology 48: 847-852

20. Legendre DP, Muzny CA, Marshall GD, Swiatlo E (2013) Antibiotic hypersensitivity reactions and approaches to desensitization. Clinical infectious diseases, p: 949 .

21. Beasley RP, Lin CC, Hwang LY, Chien CS (1981) Hepatocellular carcinoma and hepatitis b virus: A prospective study of 22707 men in Taiwan. The Lancet 318: 1129-1133.

22. Zhang W, Koehler K, Zhang P, Cook J (1995) Development of a comprehensive pharmacophore model for the benzodiazepine receptor. Drug design and discovery 12: 193-248.

23. He X, Zhang C, Cook J (2001) Model of the bzr binding site: Correlation of data from site-directed mutagenesis and the pharmacophore/receptor model. Medicinal Chemistry Research 10: 269-308.

24. Saker L, Lee K, Cannito B, Gilmore A, Campbell-Lendrum HD (2004) Globalization and infectious diseases: A review of the linkages. WHO special programme for Research, Switzerland, pp: 1-67.

25. Eswaran S, Adhikari AV, Shetty NS (2009) Synthesis and antimicrobial activities of novel quinoline derivatives carrying 1,2, 4-triazole moiety. European journal of medicinal chemistry $44: 4637-4647$.

26. Narender P, Srinivas U, Ravinder M, Rao BA, Ramesh C, et al. (2006) Synthesis of multisubstituted quinolines from baylis-hillman adducts obtained from substituted 2-chloronicotinaldehydes and their antimicrobial activity. Bioorganic \& medicinal chemistry 14: 4600-4609.

27. Koyama K, Ominato K, Natori S, Tashirot T, Tsuruo T (1988) Cytotoxicity and antitumor activities of fungal bis (naphtho-. Gamma. -pyrone) derivatives. Journal of pharmacobio-dynamics 11: 630-635.

28. Koyamas K, Natori N (1987) Chaetochromins b, c and d, bis (naphtho-. Gamma. -pyrone) derivatives from chaetomium gracile. Chemical and pharmaceutical bulletin 35: 578-584

29. Hou T, Wang J, Li Y, Wang W (2011) Assessing the performance of the $\mathrm{mm} / \mathrm{pbsa}$ and $\mathrm{mm} / \mathrm{gbsa}$ methods. 1. The accuracy of binding free energy calculations based on molecular dynamics simulations. Journal of chemical information and modeling 51: 69-82.

30. Khanna S, Bahal R, Bharatam VP (2006) In silico studies on ppary agonistic heterocyclic systems. In QSAR and molecular modeling studies in heterocyclic drugs. Topics in Heterocyclic Chemistry, India, pp: 149-180. 